\title{
ダイヤモンド/窒化物半導体ヘテロ構造の 結晶成長と物性
}

\author{
平間一行・谷保芳孝・嘉数 誠 \\ 日本電信電話株式会社 NTT 物性科学基礎研究所 画 243-0198 神奈川県厚木市森の里若宮 3-1 \\ (2010 年 10 月 6 日受理)
}

\section{Diamond/Nitride Semiconductor Heterostructure : Growth and Properties}

\author{
Kazuyuki Hirama, Yoshitaka TaniYasu and Makoto Kasu \\ NTT Basic Research Laboratories, NTT Corporation \\ 3-1 Morinosato Wakamiya, Atsugi, Kanagawa 243-0198
}

(Received October 6, 2010)

\begin{abstract}
Diamond/III-V nitride semiconductor heterostructure appears promising not only for high-efficiency deep-UV light emitting diodes (LEDs) but also for high output power field-effect transistors (FETs). However, diamond has a diamond crystal structure, while III-V nitride semiconductors have a wurtzite crystal structure. Due to the deference in the crystal structures, single-crystal III-V nitride growth on diamond substrate was difficult. In this study, we obtained the singlecrystal aluminum nitride (AIN) (0001) layers on diamond substrates by using (111) diamond surface orientation and preventing the formation of the interface layer. Then, we revealed the heteroepitaxial growth mechanism and proposed an atomic arrangement model at the diamond/AlN heterointerface. Furthermore, we demonstrated a p-type diamond/ntype AlN heterojunction diode and successfully observed band-edge emission from diamond. In addition, an AlGaN/ GaN heterostructure with two-dimensional electron gas (2DEG) was grown on diamond (111) using the single-crystal AlN buffer layer.
\end{abstract}

KEYWORDS : diamond, III-V nitride, aluminum nitride, heteroepitaxial growth mechanism, heterojunction diode

\section{1.は じめに}

ダイヤモンドは $5.5 \mathrm{eV}$ のバンドギャップエネルギー を有する間接遷移型半導体であり, 物質中最高の熱伝導 率 $(22 \mathrm{~W} / \mathrm{cmK})$ や高い絶縁破壊電界 $(10 \mathrm{MV} / \mathrm{cm}$ 以 上), 高いキャリア速度 $\left(1-2 \times 10^{7} \mathrm{~cm} / \mathrm{s}\right)$ を有している (Table 1) ${ }^{1)}$ 。またアンドープの高純度ダイヤモンドでは 高い電子移動度 $\left(>4500 \mathrm{~cm}^{2} / \mathrm{Vs}\right)$ と正孔移動度 $\left(>3800 \mathrm{~cm}^{2} / \mathrm{Vs}\right)$ が得られる。現在, $\mathrm{n}$ 型ドーピングで は P (リン) がドナーとして利用されているが2), イオ ン化エネルギーが非常に大きいため, 室温で高い電子濃 度の $\mathrm{n}$ 型層は得られていない。一方, $\mathrm{p}$ 型ドーピングで

E-mail : k.hirama@will.brl.ntt.co.jp
はB（ボロン）がアクセプタとして利用されており，高 濃度 B ドーピングが可能であることから室温で $10^{20}$ $\mathrm{cm}^{-3}$ を越える高い正孔濃度が得られる ${ }^{3)}$ 。高い絶縁破 壊電界やキャリア速度からダイヤモンドは高周波高出力 電子デバイスへの応用が期待されており, 水素終端表面 近傍に生じる二次元正孔ガスを利用した $\mathrm{p}$ チャル電界 効果トランジス夕（FET）ではすでに $100 \mathrm{GHz}$ を越える 高周波動作 ${ }^{4}$ や $2 \mathrm{~W} / \mathrm{mm}$ を越える高出力動作が実証され ている $(\text { Fig. 1 })^{5,6)}$ 。しかし，アンドープダイヤモンド の高いキャリア移動度を活かした高周波電子デバイスは 実現していない。

一方, III 族窒化物半導体は直接遷移型半導体であり, バンドギャップエネルギーは $\mathrm{AlN}$ で $6.0 \mathrm{eV}, \mathrm{GaN}$ で 3.4 $\mathrm{eV}, \mathrm{InN}$ で $0.7 \mathrm{eV}$ である。これらの混晶は組成を変え 
Table 1 (color online). Properties of diamond and III-V nitride semiconductor (AIN).

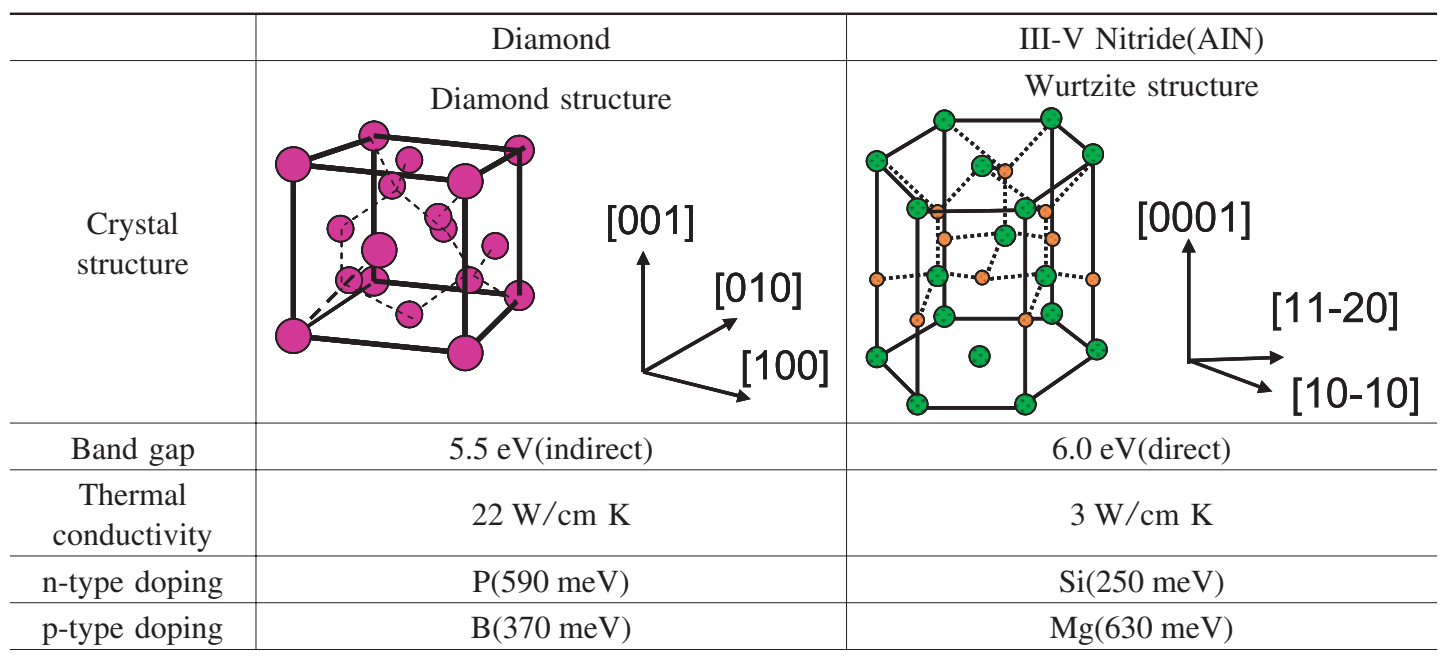

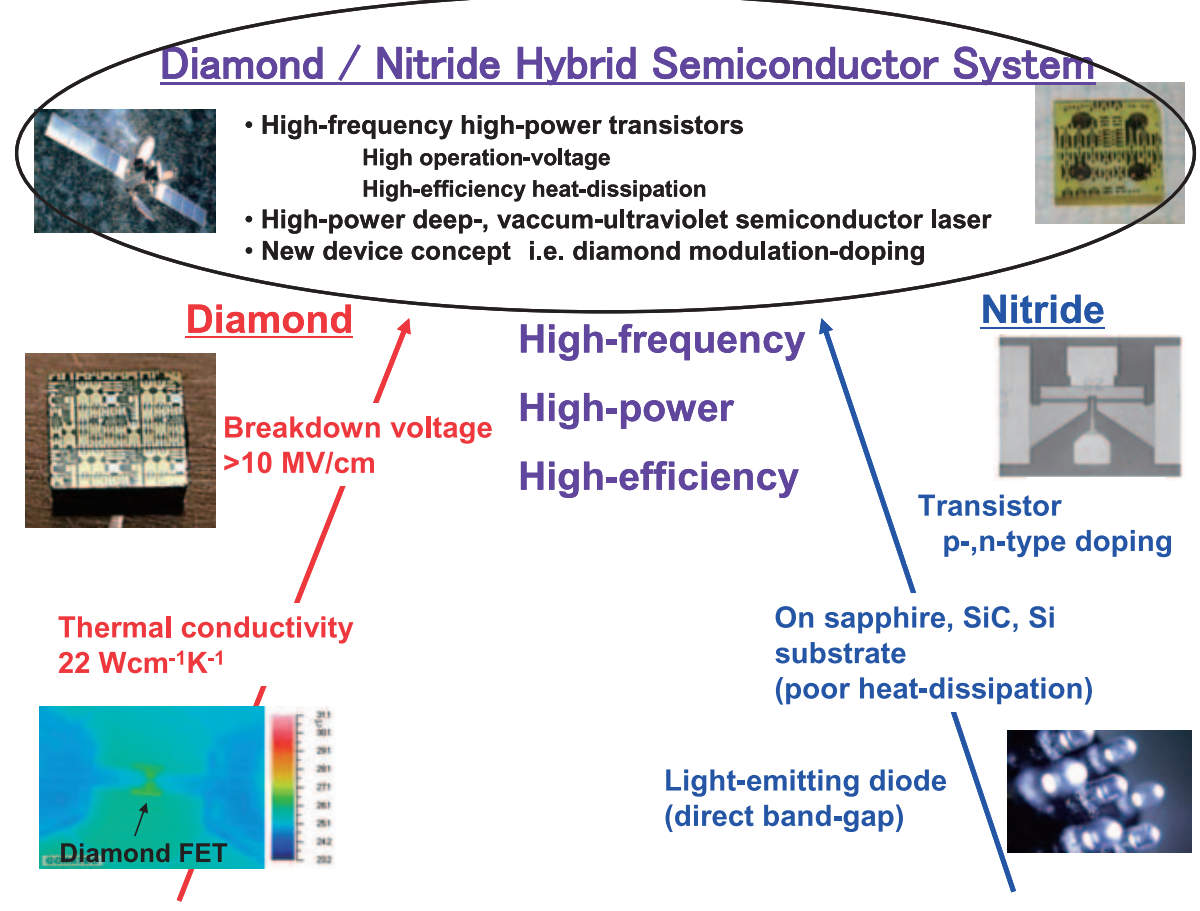

Fig. 1. (color online). Diamond/nitride hybrid semiconductor system.

ることでバンドギャップエネルギーを連続的に制御でき る7)。III 族窒化物半導体ではドナーのイオン化エネルギ 一は小さく, 室温で高い電子濃度の $\mathrm{n}$ 型層の形成が可能 であるが7 10), アクセプタのイオン化エネルギーは大き く, 室温で高い正孔濃度の $\mathrm{p}$ 型層の形成は困難である (Table 1)。窒化物半導体はバンドギャップエネルギー が大きく，またへテロ接合を形成できることから，遠紫 外 AlN 発光ダイオード (LED) ${ }^{11)}$ や, 変調ドーピングを
利用した高周波高出力 $\mathrm{AlGaN} / \mathrm{GaN}$ ヘテロ接合トランジ ス夕 (HEMT) への応用が期待されている（Fig. 1) ${ }^{12 \sim 14)}$ 。しかし遠紫外 LED では, 高い正孔濃度の p 型 層が得られていないため, LED の高効率化が制限され ている。また $\mathrm{AlGaN} / \mathrm{GaN}$ HEMT では, 基板材料（サフ アイア, $\mathrm{Si}, \mathrm{SiC})$ の低い熱伝導率によって高出力化が 制限されている ${ }^{14)}$ 。

ダイヤモンドと III 族窒化物半導体は, 上述のように 
ドーピング特性や熱伝導率などで互いに相補的な物性を 数多く有している。そこで, ダイヤモンド/III 族窒化物 半導体へテロ構造の形成が可能になれば, 高い正孔濃度 の $\mathrm{p}$ 型ダイヤモンドと高い電子密度の $\mathrm{n}$ 型窒化物半導体 による高効率の遠紫外 LED や, 物質中最高の熱伝導率 を有するダイヤモンドを基板として用いることによる $\mathrm{AlGaN} / \mathrm{GaN}$ HEMT の高出力化が可能となる。さらにダ イヤモンド/III 族窒化物半導体へテロ構造による変調ド ーピングが可能となれば，アンドープダイヤモンドの高 いキャリア移動度を利用した高周波ダイヤモンドデバイ スも期待できる（Fig. 1)。

III 族窒化物半導体とダイヤモンドのへテロ構造の形 成には, ダイヤモンド基板上での窒化物半導体の単結晶 ヘテロエピタキシャル成長が不可欠である。しかし Table 1 に示すように, ダイヤモンドは立方晶のダイヤモ ンド構造, 窒化物半導体は六方晶のウルツ鉱構造と結晶 構造が異なるためダイヤモンド基板上で窒化物半導体の 単結晶成長は非常に困難である。これまでに, 有機金属 気相成長 (MOCVD) 法や分子線エピタキシー（MBE） 法を用いたダイヤモンド（001）基板上の $\mathrm{GaN}$ や AlN の成長は複数報告されているが, 得られた窒化物層は, $\mathrm{c}$ 軸方向が揃っていないチルトドメインや異なる面内配 向関係を持つ回転ドメインからなる多結晶構造であっ $た^{15 \sim 17)}$ 。

近年，我々はダイヤモンドの（111）面の原子配列が 窒化物半導体の（0001）面と類似していることに着目し (Fig. 2)，（111）面方位のダイヤモンド基板を用いるこ
Diamond

Diamond structure

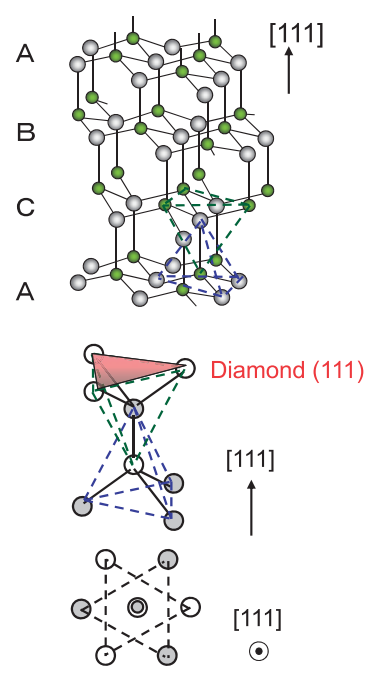

AIN Wurtzite structure [0001]
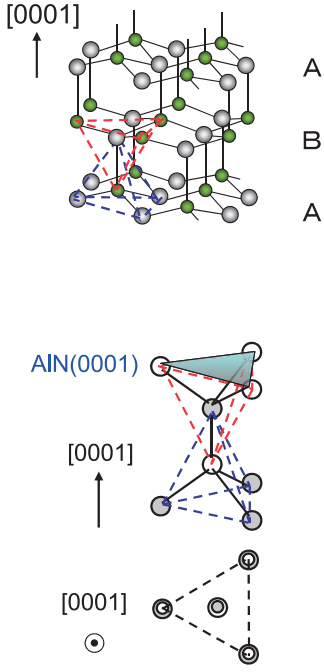

Fig. 2. (color online). Atomic arrangements of diamond (111) and AlN (0001).
とにより，ダイヤモンド基板上での単結晶 AlN の成長 に成功した ${ }^{18}$ 。本研究紹介では, 最初にダイヤモンド/ AlN ヘテロ構造の単結晶成長機構とへテロ界面構造につ いて説明する。次にダイヤモンド/AlN ヘテロ構造の応 用として, $\mathrm{p}$ 型ダイヤモンド/ $\mathrm{n}$ 型 AlN ヘテロ接合ダイ オードとダイヤモンド上の $\mathrm{AlGaN} / \mathrm{GaN}$ ヘテロ構造につ いて紹介する。

\section{2. ダイヤモンド上での窒化物半導体の結晶成 長方法}

窒化物薄膜は MOCVD 法によりダイヤモンド（111） 基板上に成長した。まず窒化物薄膜の成長前に, ダイヤ モンド表面を水素雲囲気でサーマルクリーニングする。

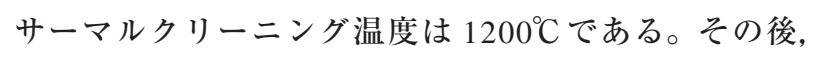
トリメチルアルミニウムをアルミニウム原料に, トリメ チルガリウムをガリウム原料に, アンモニアを窒素原料 に, 水素をキャリアガスに用いて窒化物薄膜を成長す る。AlN は $1200^{\circ} \mathrm{C}, \mathrm{GaN}$ は $1000^{\circ} \mathrm{C} て ゙$ 成長した。

MOCVD 法によりダイヤモンド基板上に単結晶 AlN を成長するには, 成長前に行う高温かつ水素雲囲気での ダイヤモンド表面のサーマルクリーニングとダイヤモン ド（111）面方位の利用が必要不可欠である。文献 18） で我々が報告しているように，サーマルクリーニング温 度を $1000^{\circ} \mathrm{C}$ 以下とした場合, ダイヤモンド（111）基板 と AlN 薄膜の間にアモルファスカーボンなどの界面層 が形成する。その界面層上に成長した AlN 薄膜は複数 の回転ドメインで構成された多結晶構造となる ${ }^{18)}$ 。一 方, サーマルクリーニング温度をより高温の $1200^{\circ} \mathrm{C}$ と した場合，ダイヤモンド（111）基板と $\mathrm{AlN}$ 薄膜の間に 界面層は形成せず, AlN 薄膜は単結晶構造となる。ま た，ダイヤモンドの面方位を従来の（001）面とした場 合では，サーマルクリーニング温度にかかわらず，ダイ ヤモンド基板上に成長した AlN 薄膜は多結晶構造であ った。

ダイヤモンド基板上に $\mathrm{GaN}$ 薄膜や $\mathrm{AlGaN}$ 薄膜を成長 する場合も，上記の方法でまずダイヤモンド基板上に単 結晶 AlN 薄膜をバッファ層として形成した。これは, $\mathrm{GaN}$ や $\mathrm{AlGaN}$ 薄膜をダイヤモンド基板上に直接成長す ると, 核形成密度が低いため連続膜とならないが, AlN バッファ層を用いることにより $\mathrm{GaN}$ や $\mathrm{AlGaN}$ 薄膜は二 次元的に成長するためである。

\section{3. ダイヤモンド上の単結晶 AIN 成長機構の 解明}

\section{1 成長初期の AIN 構造とへテロ界面構造の観察}

ダイヤモンド（111）基板上での単結晶 AlN 成長機構 
を明らかにするため，AlNの成長初期を評価した。Fig. 3 (a)，（b）は膜厚 $60 \mathrm{~nm}$ の AlN 薄膜の AlN（0002）面 と（10-11）面の X 線極点図である。極点図測定では, 試料に対する $\mathrm{X}$ 線の入射角 $(\omega)$ と検出器の角度 $(2 \theta)$ を特定のブラッグ角に固定し，試料を直行する 2 軸（試 料の仰角 $(\Psi)$ と回転角 $(\phi))$ の回りに系統的に回転さ せることにより，成長した試料における特定の面方位の 分布が得られる。Fig. 3 では, AlN の [0001］方位と [10-11］方位が基板に対してどの方向を向いているかが わかる。本測定では $\phi=0^{\circ}$ をダイヤモンド（111）基板 の [1-10] 方位, $\Psi=0^{\circ}$ を[111] 方位とした。Fig. 3 （a）では，強度の強いピークが $\Psi=0^{\circ}$ にのみ見られた。 これはAlNの [0001］方位がダイヤモンドの [111］方 位にのみ配向しており, ダイヤモンド（111）基板にチ ルトドメインが形成していないことを示している。一 方, Fig. 3(b) では, $\Psi=62^{\circ}$ において, $\phi=0^{\circ}, 60^{\circ}$, $120^{\circ}, 180^{\circ}, 240^{\circ}, 300^{\circ}$ に 6 つの回折ピークが見られ た。 $\Psi$ の角度 $\left(62^{\circ}\right)$ は AlN (0001) 面と AlN (10-11) 面の成す角度 $61.6^{\circ}$ とほほ一致していること, また六方 晶 AlN は 6つの等価な（10-11）面を持つことから, Fig. 3（b）に打ける 6つの回折ピークは, ダイヤモンド （111）面に [0001］配向した AlN 層の（10-11）面によ るものと思われる。以上の結果から, AlN とダイヤモン ドは結晶構造が異なるにもかかわらず, ダイヤモンド （111）基板上では成長初期過程から単結晶 AlN が成長 することがわかった。ダイヤモンドと単結晶 AlN の配
向関係は [0001］AlN//[111］diamond, [10-10］AlN// [1-10] diamond である。

Fig. 4 はダイヤモンド（111）基板上に成長した膜厚 $60 \mathrm{~nm}$ の AlN 薄膜表面の SEM 像である。六方晶 AlN の 結晶構造に対応した六角形状の成長核が形成している。 それぞれの成長核の方位は一致している。 AlN 成長核の [10-10］方向はダイヤモンド基板の [1-10］方向に平行 であり，X 線極点図測定の結果（Fig. 3）と同じである。

次に単結晶 AlN（0001)/ダイヤモンド（111）へテロ 接合界面の原子配列を明らかにするため, へテロ界面の 高分解能断面 TEM 観察を行った（Fig. 5 (a))。TEM 像 はダイヤモンド [11-2］方位に沿って観測した。AlN と

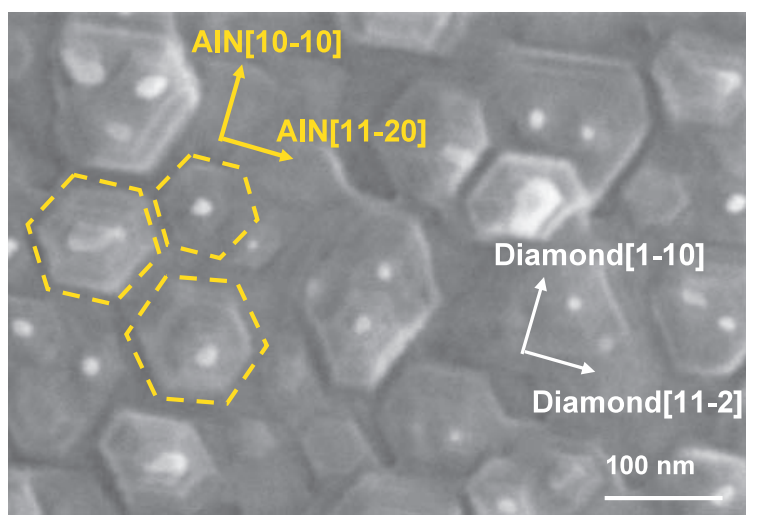

Fig. 4. (color online). SEM image of the 60-nm-thick AlN layer on the diamond (111) substrate.

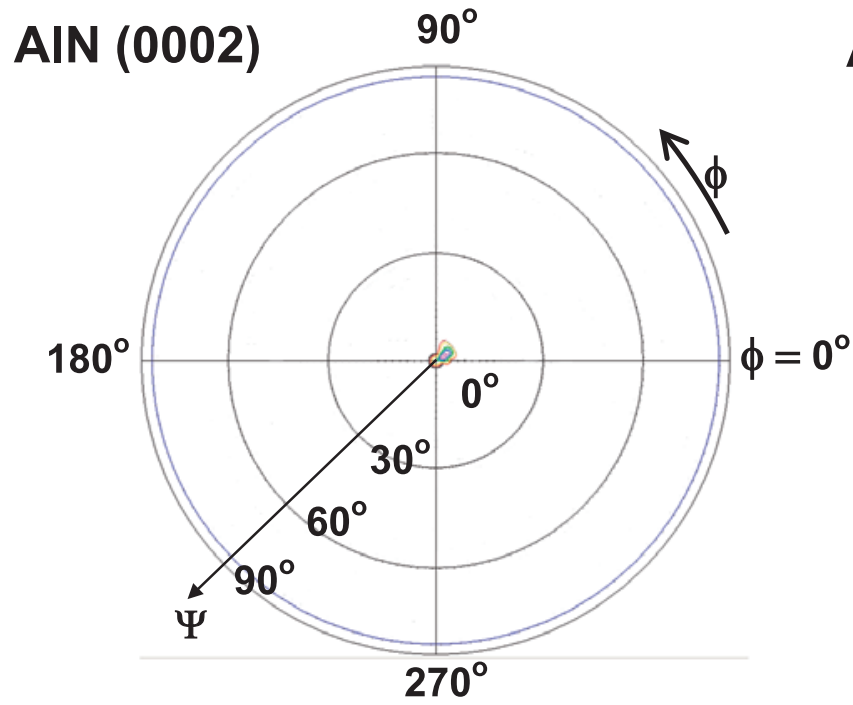

(a)

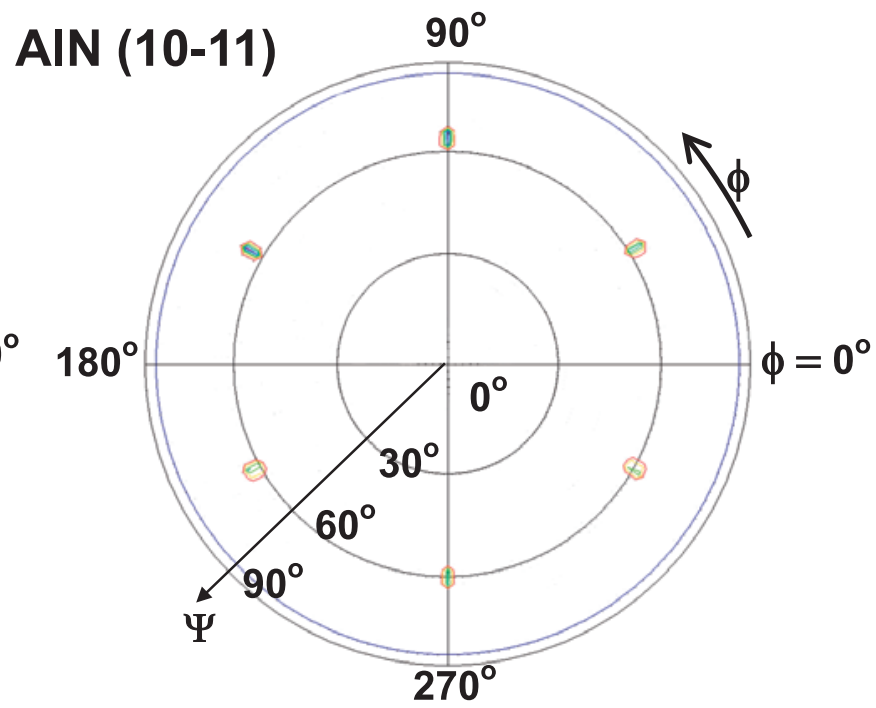

(b)

Fig. 3. (color online). XRD pole figures of (a) AIN (0002) and (b) AIN (10-10) planes of the 60-nm-thick AlN layer grown on the diamond (111) substrate. 
ダイヤモンドの間に界面層は見られず，矢印で示した位 置に急峻なへテロ界面が形成している。これより，ダイ ヤモンド（111）表面から単結晶 AlN（0001）層が直接 ヘテロエピタキシャル成長していることがわかる。

Fig. 5 （b）に我々が提案するダイヤモンド/AlN ヘテ ロ界面の原子配列モデル, Fig. 5 (c) にそのモデルと TEM 像を重ね合わせたものを示す。Fig. 5（a）におけ る明るいスポットは，観察方向から見た際に近接してい る原子対に対応しており,ダイヤモンド層では C-C 原 子対, AlN 層では Al-N 原子対に対応する。この Al-N 原子対の $\mathrm{Al}$ 原子と $\mathrm{N}$ 原子の位置関係は $\mathrm{AlN}$ 層の極性に よって決まる。ダイヤモンド（111）基板上に成長した 単結晶 AlN（0001）層の極性は収束電子線回折 （CBED）法から Al 極性であることを確認しており ${ }^{18)}$, Fig. 5 （c）に示すように Al-N 原子対の上部が $\mathrm{Al}$ 原子, 下部が $\mathrm{N}$ 原子となる。一方，ダイヤモンド/AlN ヘテロ 界面では，C-N 結合と C-Al 結合の二通りの可能性が考 えられるが， C-N 結合と C-Al 結合の結合エネルギーは それぞれ $2.6 \mathrm{eV}, 2.1 \mathrm{eV}$ であるため，へテロ界面では C-N 結合が C-Al 結合と比べて安定である。その結果, Fig. 5（b）に示すようにへテロ界面では C-N 結合が形 成している。へテロ界面の $\mathrm{C}-\mathrm{N}$ 結合は, $\mathrm{AlN}$ 層の $\mathrm{Al}$ 極 性ともつじつまが合う。また Fig. 5 （b)，（c）中では, AlN [10-10］方向に 4 本のミスフィット転位の形成が 確認できるが，このミスフィット転位はダイヤモンドと AlN の大きな格子不整合（-28.8\%）に起因している。

\section{2 ダイヤモンド上の単結晶 AIN 成長モデルの提案} 次にダイヤモンド/単結晶 AlN（0001）へテロ構造の 面内配向関係について考察する。上述の通り，ダイヤモ ンド/単結晶 AlN（0001）の面内配向関係は [10-10] AlN//[1-10] diamond であり, ダイヤモンドと AlN の 格子定数差から計算される格子不整合度は $-28.8 \%$ であ る。もし，面内配向関係が [10-10］AlN//[1-12］ diamond となった場合の格子不整合度は $25.6 \%$ となり, 実 際の面内配向関係の格子不整合度 $(-28.8 \%)$ よりも小 さく，ダイヤモンド（111）基板上と単結晶 AlN（0001） 薄膜の面内配向関係は格子不整合度では説明できない。

一般的にへテロ界面に扔ける面内配向関係は界面エネ ルギーが最小になるように決まるが，その場合この界面 エネルギーは次のように表せる。

$$
\sigma_{\text {interface }}=\sigma_{\text {substrate }}+\sigma_{\text {film }}-\gamma
$$

ここで $\sigma_{\text {substrate }}, \sigma_{\text {film }}, \gamma$ は基板材料の表面エネルギー, 成長した薄膜の表面エネルギー, 付着エネルギーであ る。基板材料と成長した薄膜の表面エネルギーはそれぞ れの面方位に依存する。面内配向関係だけが異なる場合 は，それぞれの面方位は変化せず，界面エネルギーの違 いは付着エネルギーのみによって決まり，この付着エネ ルギーはへテロ界面に扔ける結合密度に比例する。基板 材料と成長薄膜の格子不整合が小さいへテロ系の場合 は, 格子不整合度が最も小さい面内配向関係で結合密度 が最も高くなり, 界面エネルギーが最小になる。一方, AIN とダイヤモンドのように格子不整合が非常に大きい

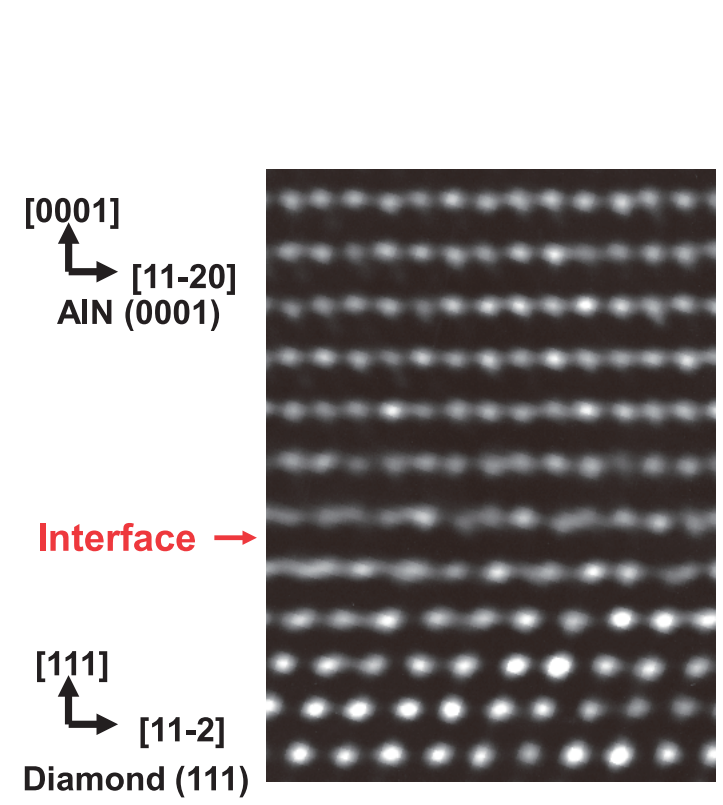

(a)

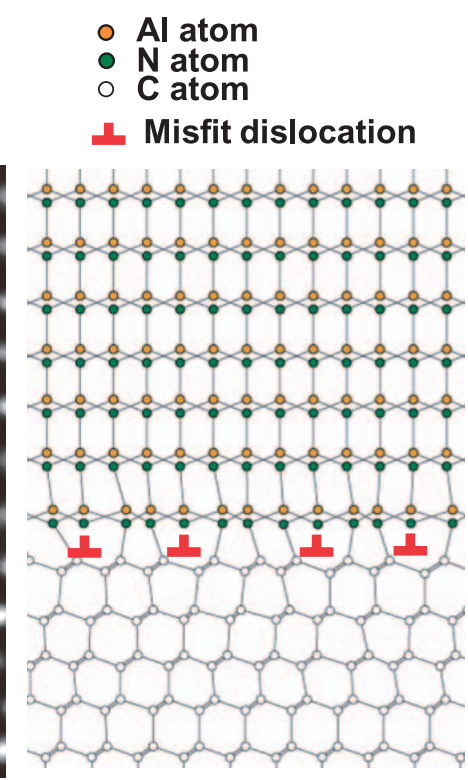

(b)

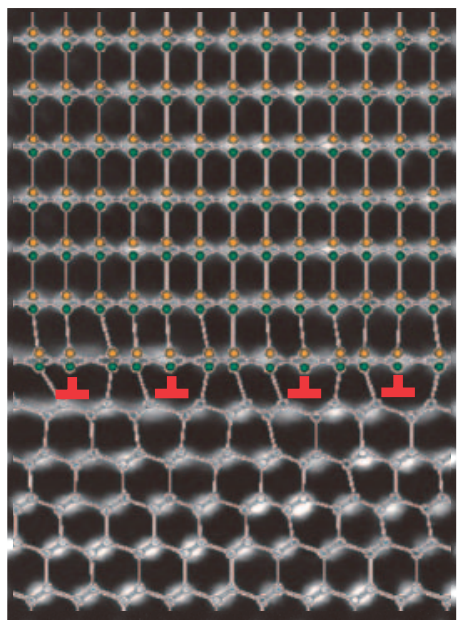

(c)

Fig. 5. (color online). (a) HR-TEM image at the diamond (111)/AIN (0001) heterointerface. (b) Atomic arrangement model based on the HR-TEM image. (c) Superimposition of (a) and (b). 


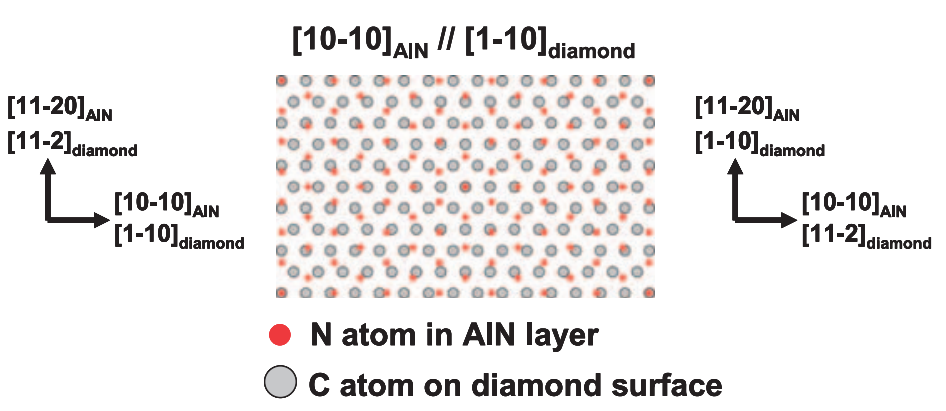

(a)

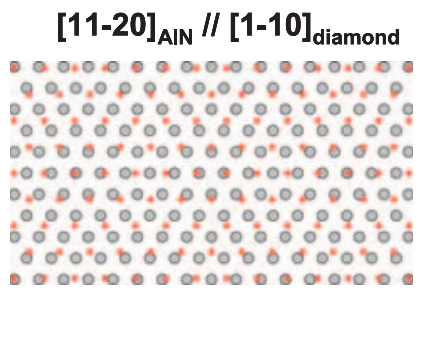

(b)

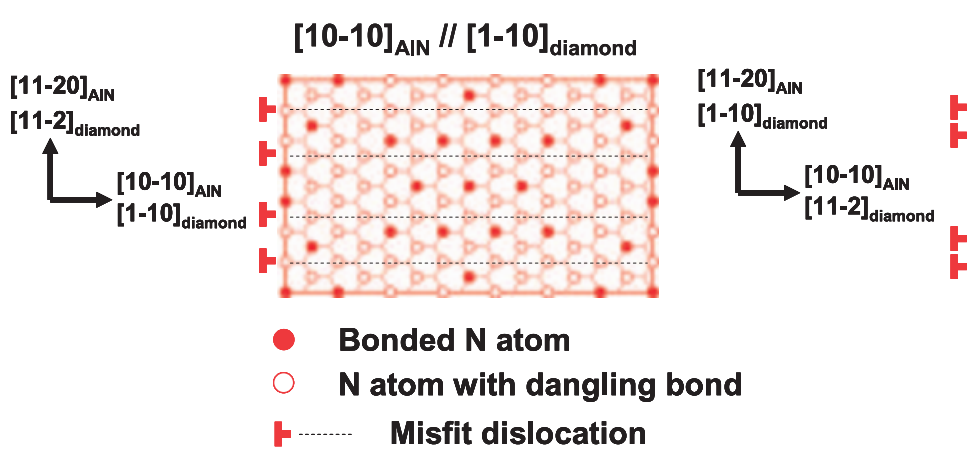

(c)

(d)

Fig. 6. (color online). Schematic top views of the diamond (111)/AlN (0001) interface for (a) [10-10] AlN//[1-10] diamond and (b) [11-20] AlN//[1-10] diamond. Distribution of $\mathrm{N}$ atoms bonded to $\mathrm{C}$ atoms at the AlN (0001)/diamond (111) interface for (c) [10-10] AlN//[1-10] diamond and (d) [11-20] AlN//[1-10] diamond.

ヘテロ系の場合は, 格子不整合度が小さい面内配向関係 であってもへテロ界面の結合密度が必ずしも最大となる とは限らない。

そこで, [10-10] A1N//[1-10] diamond と [10-10] AlN//[1-12］ diamond の二通りの面内配向関係の結合構 造について考察し, 結合密度を見積った。Fig. 6 (a), （b）は AlN [0001］方向から見たへテロ界面の結合モデ ルであり, ヘテロ界面に最も近い $\mathrm{AlN}$ 層の $\mathrm{N}$ 原子とダ イヤモンド層の $\mathrm{C}$ 原子のみを示している。Fig. 6 (c), (d) はへテロ界面における C-N 結合（○）とダングリ ングボンド $(\bigcirc)$ の分布を示す。 [10-10］A1N//[1-10] diamond と [10-10］AlN//[1-12］ diamond の面内配向関 係の場合のへテロ界面の結合密度は, それぞれ $2.7 \times 10^{14} \mathrm{~cm}^{-2}$ と $2.2 \times 10^{14} \mathrm{~cm}^{-2}$ になる。したがって, [10-10] AlN//[1-10] diamondの方が [10-10] AlN// [1-12］diamondよりも結合密度が高いため界面エネル ギーは小さくなる。この結果, ダイヤモンド/AlNへテ 口接合の面内配向関係は [10-10］ AlN//[1-10］ diamond になると考えられる ${ }^{19)}$ 。

ところで, Fig. 6 (c), （d）において直線状に配列し たダングリングボンドはミスフィット転位であり, 点線
はそれぞれの配向関係において AlN [10-10］方向に導 入されるミスフィット転位を示している。[10-10] AlN//[1-10] diamond の面内配向関係の結合構造モデル から予想されるミスフィット転位の周期は, 断面 TEM 像で観察されたミスフィット転位の周期と一致すること がわかる。

\section{4. $\mathbf{p}$ 型ダイヤモンド/n 型 AIN ヘテロ構造の 作製と電子物性}

ダイヤモンド/A1Nヘテロ構造のデバイス応用には, ダイヤモンド基板上に成長した AlN の電気伝導性制御 が不可欠である。ダイヤモンド基板上に成長した A $1 \mathrm{~N}$ への Si ドーピングは 2003 年に Miskys らにより報告さ れているが, 明確な $\mathrm{n}$ 型伝導は確認されていない ${ }^{20)}$ 。こ れはダイヤモンド基板上に成長した A IN が多結晶であ ったためと考えられる。そこで我々は, Si ドーピング による AlN の n 型伝導には単結晶 AlN が不可欠と考え, ダイヤモンド（111）基板上に成長した単結晶 AlNへの Si ドーピングを行った。Fig. 7 (a)，（b）はホール効果 により測定した Si ドープ単結晶 AlN の電子濃度と移動 度の温度依存性である。全温度範囲で $\mathrm{n}$ 型伝導性を示 


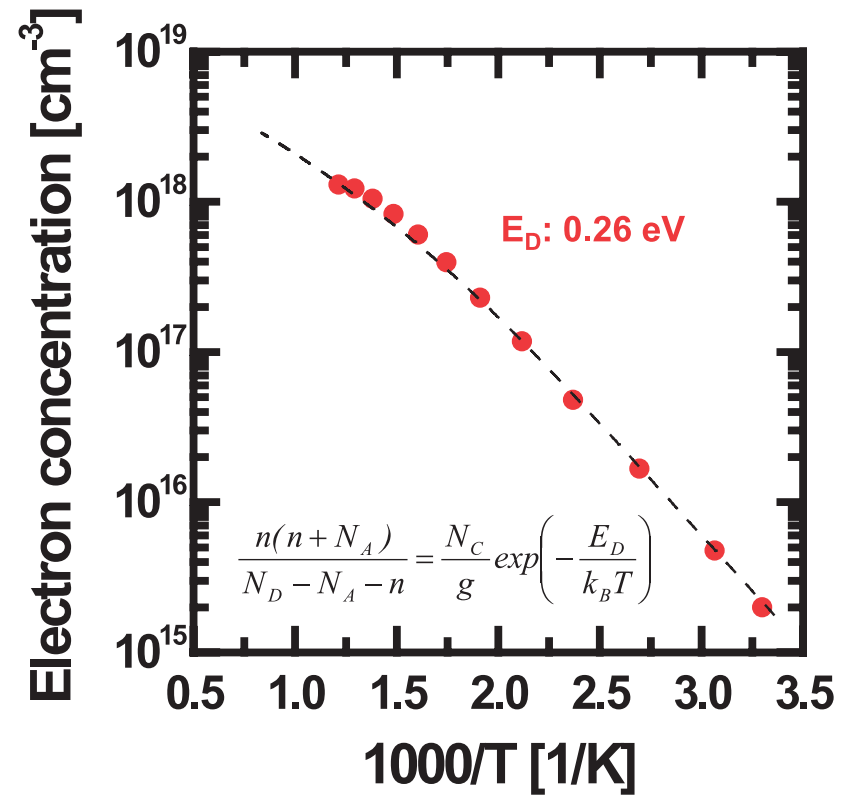

(a)

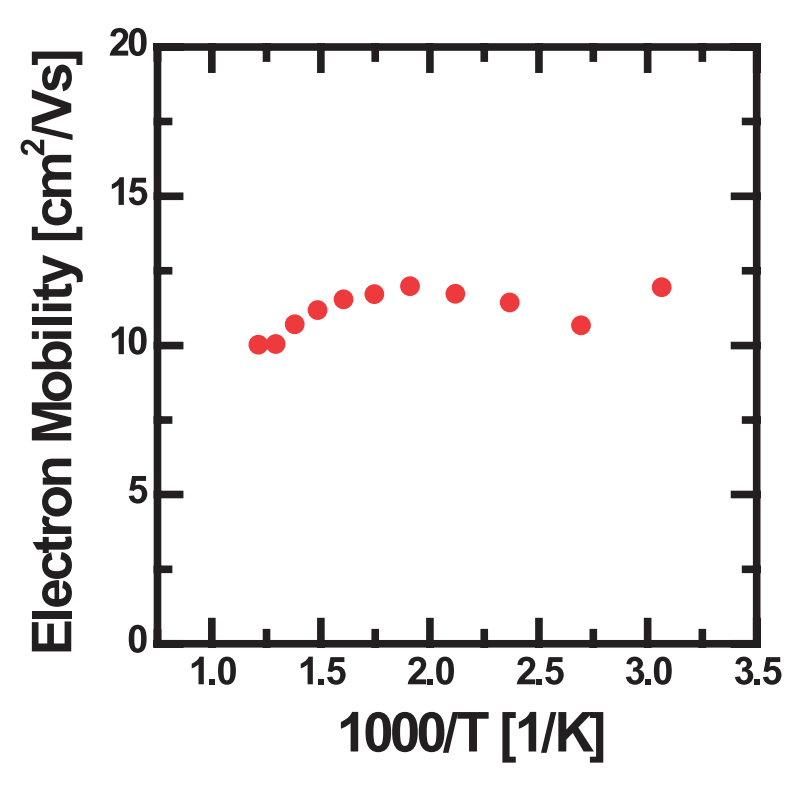

(b)

Fig. 7. (color online). Temperature dependence of (a) electron concentration and (b) electron mobility in the Si-doped AlN layer grown on diamond (111) substrate.

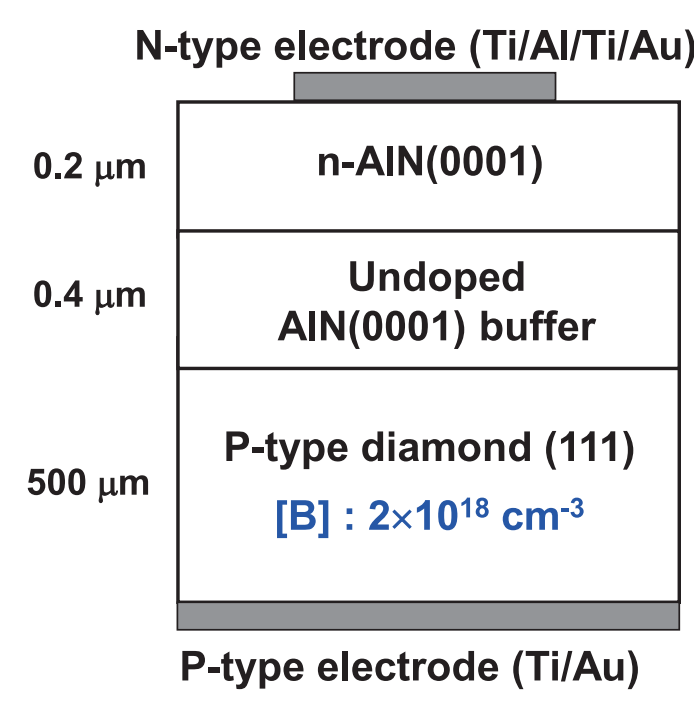

(a)

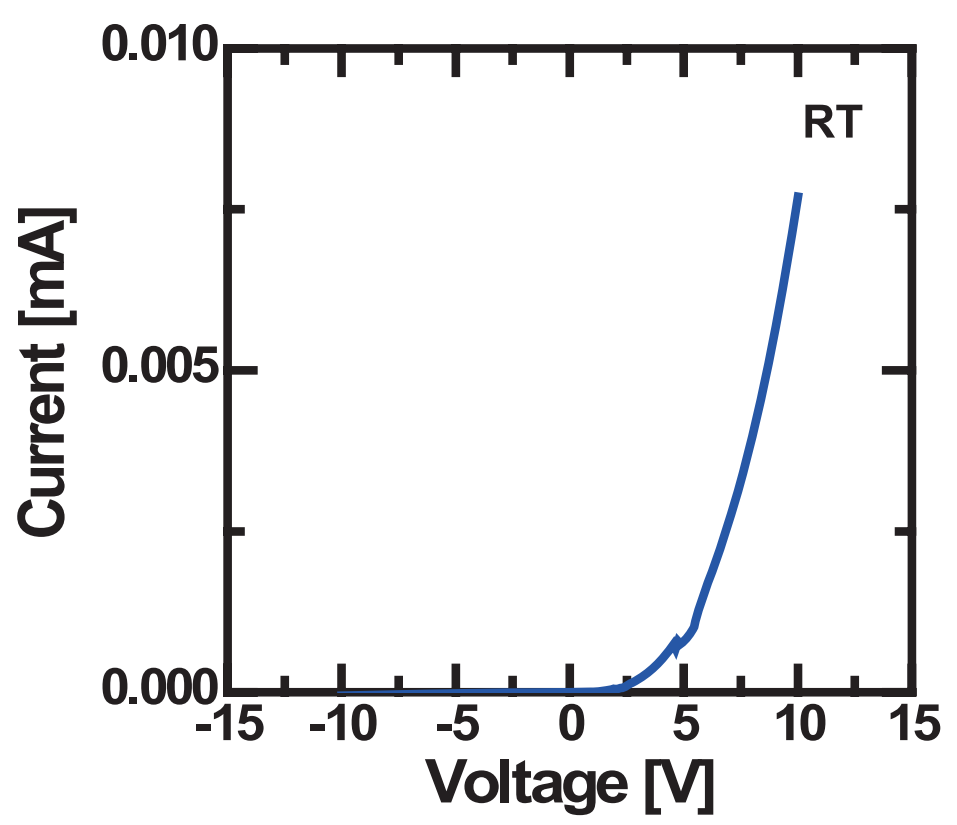

(b)

Fig. 8. (color online). (a) Schematic and (b) I-V characteristics of the p-type diamond/n-type AlN heterojunction diode (Sample A).

し，室温では電子濃度と移動度はそれぞれ $2.0 \times 10^{15}$ $\mathrm{cm}^{-3}, 12 \mathrm{~cm}^{2} / \mathrm{Vs}$ になった。電子濃度の温度依存性を電 荷中性条件により解析し, ドナーのイオン化エネルギー とドナー濃度をそれぞれ $0.26 \mathrm{eV}, 7.8 \times 10^{18} \mathrm{~cm}^{-3}$ と見積
もった。このドナーのイオン化エネルギーは AlN 中の $\mathrm{Si}$ ドナーのイオン化エネルギー $(0.25 \mathrm{eV})$ とほぼ一致 すること, またドナー濃度は二次イオン質量分析法 (SIMS 測定) より求めた AlN 中の $\mathrm{Si}$ 濃度 $\left(7.5 \times 10^{18}\right.$ 
$\left.\mathrm{cm}^{-3}\right)$ とほぼ同じであることから, $\mathrm{n}$ 型伝導性は $\mathrm{AlN}$ 中の Si ドナーに由来すると結論づけることができる。 以上の結果から, ダイヤモンド基板上で初めて $\operatorname{AlN} の$ $\mathrm{n}$ 型伝導を確認した。

次にこの $\mathrm{n}$ 型単結晶 AlN を利用して Fig. 8 (a) に示 す $\mathrm{p}$ 型ダイヤモンド/ $\mathrm{n}$ 型 AlN ヘテロ接合ダイオードを 作製した。まず $\mathrm{B}$ ドープ $\mathrm{p}$ 型ダイヤモンド（111）基板 上に膜厚 $400 \mathrm{~nm}$ のアンドープ単結晶 AlNを介して, そ の上に膜厚 $200 \mathrm{~nm}$ の Si ドープ $\mathrm{n}$ 型単結晶 AlN を成長

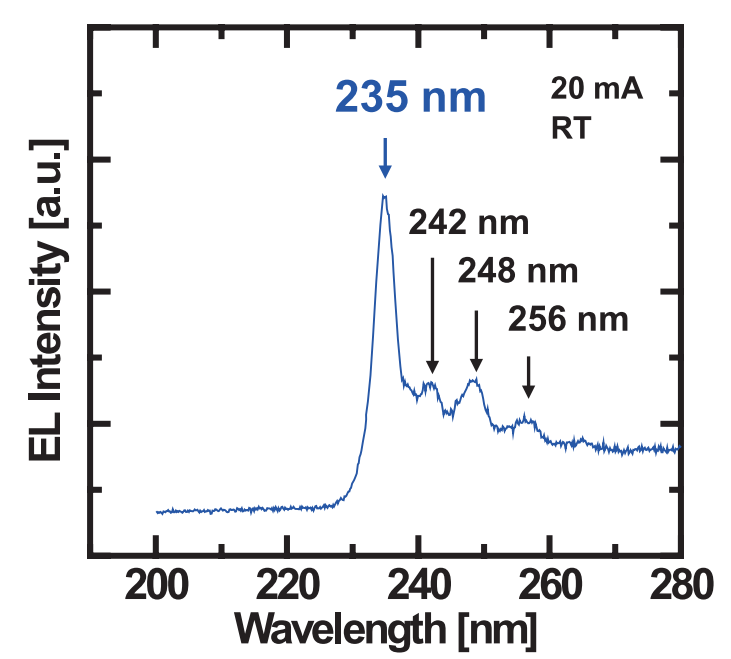

Fig. 9. (color online). Current-injected emission spectrum of the p-type diamond/n-type AlN heterojunction diode (Sample A).
した（サンプル $\mathrm{A} ）$ 。 $\mathrm{p}$ 型ダイヤモンド基板の $\mathrm{B}$ 濃度は $2 \times 10^{18} \mathrm{~cm}^{-3}, \mathrm{n}$ 型 $\mathrm{AlN}$ の $\mathrm{Si}$ 濃度は $7.5 \times 10^{18} \mathrm{~cm}^{-3}$ あ る。続いて $\mathrm{n}$ 型 AlN と $\mathrm{p}$ 型ダイヤモンドにオーミック 電極を形成するため, $\mathrm{n}$ 型 $\mathrm{AlN}$ に直径 $400 \mu \mathrm{m}$ の $\mathrm{Ti} / \mathrm{Al} /$ $\mathrm{Ti} / \mathrm{Au}$ 電極, $\mathrm{p}$ 型ダイヤモンド基板全面に $\mathrm{Ti} / \mathrm{Au}$ 電極を 蒸着し, 窒素雲囲気 $800^{\circ} \mathrm{C}$ でアニール処理を行った。

Fig.8（b）は室温における p 型ダイヤモンド/n 型 AlN ヘテロ接合ダイオードの電流・電圧（I-V) 特性で ある。AlN とダイヤモンドの格子不整合は $-28.8 \%$ と大 きいにもかかわらず，ヘテロ接合ダイオードの明確な整 流性を確認することができた。 $10 \mathrm{~V}$ でのオンオフ比

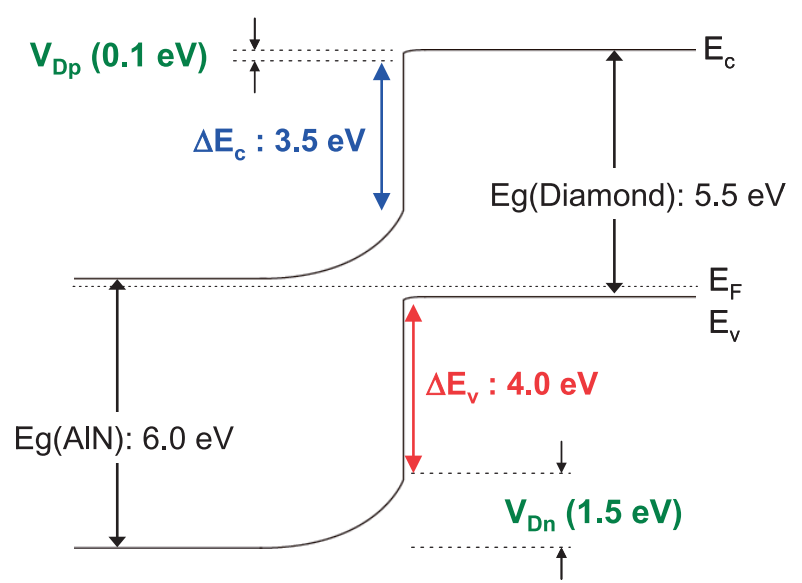

Fig. 11. (color online). Energy band alignment of the p-type diamond/n-type AlN heterojunction.
Sample B

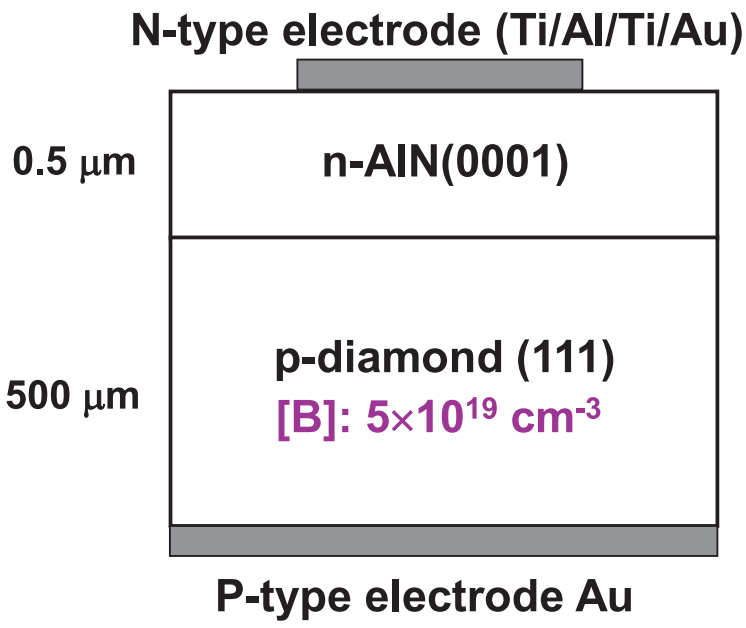

(a)

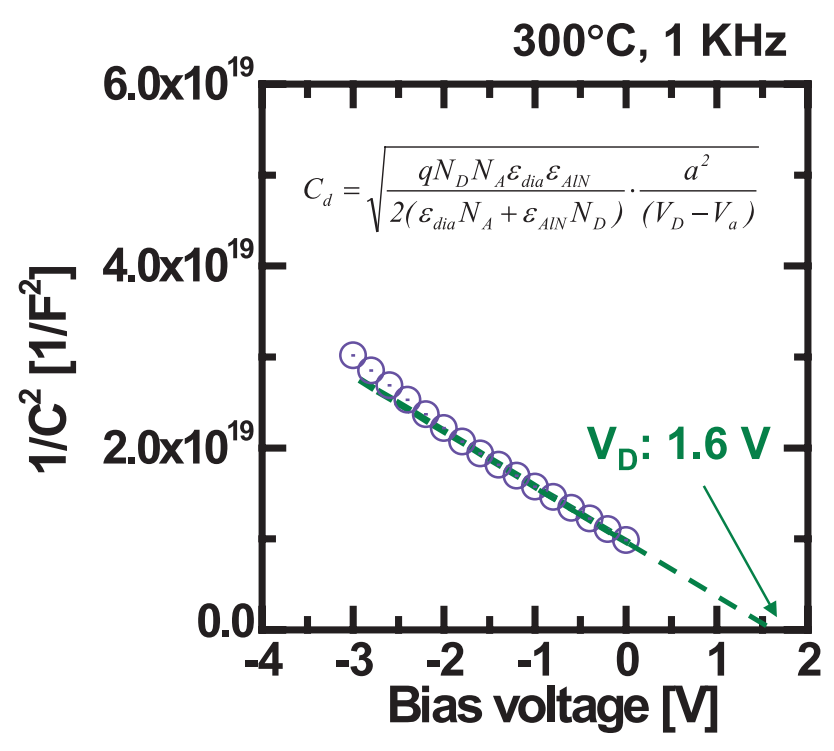

(b)

Fig. 10. (color online). (a) Schematic of the p-type diamond/n-type AlN heterojunction diode (Sample B) for C-V characteristics. (b) Bias voltage dependence of $1 / \mathrm{C}^{2}$ for the p-type diamond/n-type AlN heterojunction diode. 


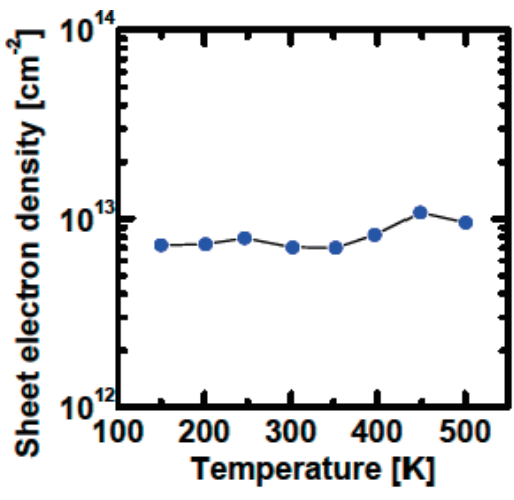

(a)

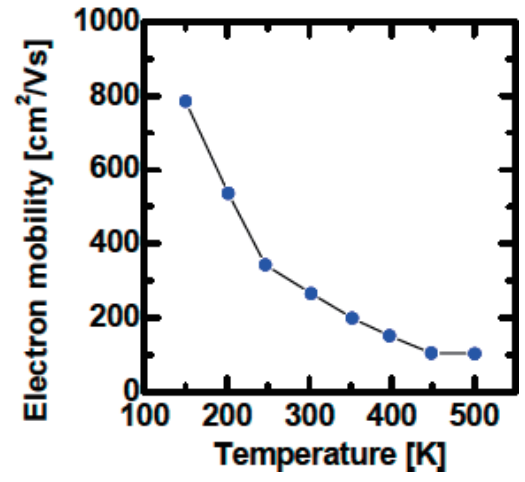

(b)

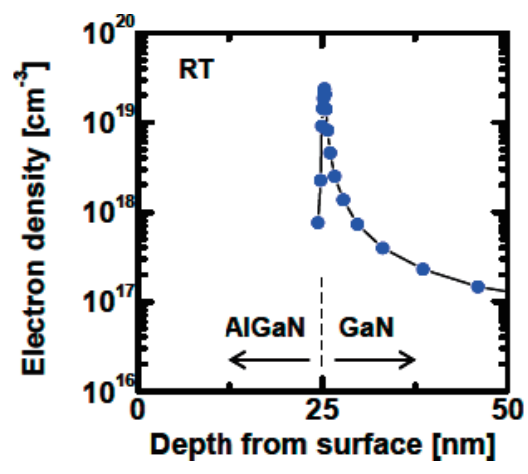

(c)

Fig. 12. (color online). Temperature dependence of (a) sheet electron density and (b) electron mobility in $\mathrm{AlGaN} / \mathrm{GaN}$ heterostructure grown on diamond. (c) Electron profile evaluated by $\mathrm{C}-\mathrm{V}$ measurement.

は 130 であった。

Fig. 9 は p 型ダイヤモンド/n 型 $\mathrm{AlN}$ ヘテロ接合ダイ オード（サンプル A）の電流注入発光スペクトルであ る。波長 $235 \mathrm{~nm}$ にダイヤモンドの自由励起子に由来す る発光ピークを観測した。235 nmよりも長波長側に観 測される発光ピークは, ダイヤモンドの自由励起子のフ オノンレプリカ $(242 \mathrm{~nm})$, 伝導帯から B アクセプタへ の遷移 $(248 \mathrm{~nm})$, 格子間の B 原子 $(256 \mathrm{~nm})$ に由来す る。これらダイヤモンドに由来する発光から, n 型 AlN から $\mathrm{p}$ 型ダイヤモンドへ電子（少数キャリア）が注入さ れていると思われる。

次にダイヤモンド/AlN へテロ接合のエネルギーバン ドアライメントを, 容量・電圧 $(\mathrm{C}-\mathrm{V})$ 特性により調査 した。C-V 測定には, B 濃度 $5 \times 10^{19} \mathrm{~cm}^{-3}$ の $\mathrm{p}$ 型ダイヤ モンド基板上に膜厚 $400 \mathrm{~nm}$ の $\mathrm{n}$ 型 $\mathrm{AlN}$ を直接成長した 構造を用いた (サンプル B)。成長した構造の模式図を Fig. 10 (a) に示す。 $\mathrm{n}$ 型 $\mathrm{AlN}$ の $\mathrm{Si}$ 濃度は $2 \times 10^{18} \mathrm{~cm}^{-3}$ である。Fig. 10（b）はサンプル B の 1/ $\mathrm{C}^{2}-\mathrm{V}$ 特性であ る。一般にイオン化エネルギーの大きいドナーやアクセ プタは, 室温ではキャリア放出時間が長く, 高い周波数 の測定信号に対して十分追従できないと考えられる。そ のため本研究では意図して低周波の $1 \mathrm{KHz}$, 高温の $300^{\circ} \mathrm{C}$ で $\mathrm{C}-\mathrm{V}$ 測定を行った。 $1 / \mathrm{C}^{2}-\mathrm{V}$ 特性はバイアス電 圧に対して線形に変化しており，外挿することにより拡 散電位を $1.6 \mathrm{eV}$ と見積った。

Fig. 11 に, $1.6 \mathrm{eV}$ の拡散電位の結果から計算した, ダイヤモンド/AIN ヘテロ界面のバンドアライメントを 示す。ダイヤモンド中の B 濃度は AlN 中の Si 濃度より も約一桁高いため, ヘテロ界面で空乏層は主に $\mathrm{n}$ 型 $\mathrm{AlN}$ 側に伸びていると考えられる。それぞれの領域での不純
物濃度と誘電率から, $\mathrm{n}$ 型 $\mathrm{AlN}$ と $\mathrm{p}$ 型ダイヤモンドでの バンドベンディングはそれぞれ $1.5 \mathrm{eV}, 0.1 \mathrm{eV}$ となる。 これらの結果から, $\mathrm{n}$ 型 $\mathrm{AlN} / \mathrm{p}$ 型ダイヤモンドへテロ接 合のバンドアライメントは Type-II（Staggered-type）で あり, 価電子帯と伝導帯のオフセットはそれぞれ 4.0 $\mathrm{eV}, 3.5 \mathrm{eV}$ と見積もった。伝導帯のオフセットが価電 子帯のオフセットよりも小さいため, p 型ダイヤモン ド/n 型 AlN ヘテロ接合では, AlN からダイヤモンドへ の電子の注入が, ダイヤモンドから $\mathrm{AlN}$ への正孔の注 入よりも容易であることが予想される。このため, Fig. 9 に示すように $\mathrm{n}$ 型 $\mathrm{AlN} / \mathrm{p}$ 型ダイヤモンドへテロ接合ダ イオード（サンプル A）ではダイヤモンドに由来する電 流注入発光が観測されたと考えられる。

\section{5. ダイヤモンド上 $\mathrm{AlGaN} / \mathrm{GaN}$ ヘテロ構造の 作製と電子物性}

ダイヤモンド上に単結晶の AlN 成長ができるように

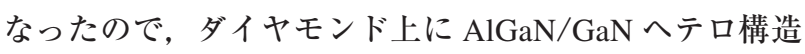
を成長した。本研究では MOVPE 法により半絶縁性ダイ ヤモンド (111) 基板上に単結晶 AlN バッファ層（180 $\mathrm{nm})$ とクラックの形成を防ぐための $\mathrm{AlN} / \mathrm{GaN}$ 多層膜 (20 周期, $\mathrm{AlN}: 3 \mathrm{~nm}, \mathrm{GaN}: 11 \mathrm{~nm}$ ) を成長後, アンド ープ $\mathrm{GaN}$ 薄膜 $(600 \mathrm{~nm})$ とアンドープ $\mathrm{Al}_{0.25} \mathrm{Ga}_{0.75} \mathrm{~N}$ 薄膜

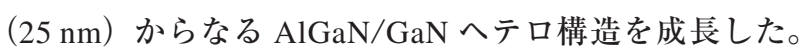
$\mathrm{AlGaN} / \mathrm{GaN}$ ヘテロ構造の電気的評価を Hall 効果測定と $\mathrm{C}-\mathrm{V}$ 測定により行った。オーミック電極は $\mathrm{Ti} / \mathrm{Al} / \mathrm{Ti} /$ $\mathrm{Au}, \quad シ ョ ッ ト キ ー は ~ \mathrm{Ni} / \mathrm{Au}$ である。

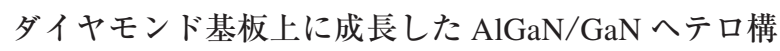
造の電子面密度と電子移動度の温度依存性を Fig. 12 (a), （b）に示す。室温での電子面密度および移動度は 
それぞれ， $8.0 \times 10^{12} \mathrm{~cm}^{-2}$ および $300 \mathrm{~cm}^{2} / \mathrm{Vs}$ であった。 電子移動度は $150 \mathrm{~K}$ で $800 \mathrm{~cm}^{2} / \mathrm{Vs}$ に達した。電子面密 度は 150-500 K の温度範囲でほほ一定であり, 電子移動 度は温度の減少とともに増加した。この電子面密度と電 子移動度の温度依存性は二次元電子ガスの特徴と一致す る。Fig. 12 (c) に室温 C-V 測定より求めた $\mathrm{AlGaN} /$ $\mathrm{GaN}$ ヘテロ構造の電子分布を示す。表面から $25 \mathrm{~nm}$ の 位置に電子が 2 次元的に蓄積していることを確認した。 $25 \mathrm{~nm}$ という值は $\mathrm{AlGaN}$ バリア層の膜厚とほぼ一致す る。以上の結果から, 窒化物半導体と結晶構造が異なる ダイヤモンド基板上で, $\mathrm{AlGaN} / \mathrm{GaN}$ ヘテロ構造に高い 電子面密度を有する二次元電子ガスが形成していること がわかった。

\section{6. 結}

\section{論}

本研究ではダイヤモンド（111）面方位を利用するこ とで急峻なへテロ界面を有する単結晶 AIN（0001）薄膜 の成長が可能であることを見出し, ダイヤモンド上の単 結晶 AIN 成長モデルを提案した。この単結晶 AlN 成長 技術を利用することによりダイヤモンド上の単結晶 $\mathrm{n}$ 型 AlN 成長が可能となり, $\mathrm{n}$ 型 AlN $/ \mathrm{p}$ 型ダイヤモンドへテ ロ接合ダイオードではダイヤモンドのバンド端に由来す る電流注入発光が得られた。また, 単結晶 AlNをバッ ファ層として利用することで, ダイヤモンド基板上で二 次元電子ガスを有する $\mathrm{AlGaN} / \mathrm{GaN}$ ヘテロ構造の成長も 可能となった。ダイヤモンド/窒化物半導体へテロ構造 はダイヤモンドと窒化物半導体の両者の特徴を利用でき る点で有望であり，これによりそれぞれの材料単独では 得られない新しい物性の発現や新規デバイスが期待できる。

\section{謝辞}

ヘテロ接合ダイオードと $\mathrm{AlGaN} / \mathrm{GaN}$ ヘテロ構造の作 製と評価には, 山内喜晴氏に協力いただいた。ダイヤモ ンド/AlNヘテロ界面の断面 TEM 観察には, NTT-AT 分 析センターの水野誠一郎氏, 見立壽継氏に協力いただい た。本研究は, 総務省 SCOPE「ダイヤモンド・高周波 電力デバイスの開発とマイクロ波・ミリ波帯電力増幅器 への応用」プロジェクトの一部である。

\section{文献}

1) L.S. Pan and D.R. Kania : Diamond : "Electronic Properties and Applications” (Springer, 1995).

2) S. Koizumi, M. Kamo, Y. Sato, H. Ozaki and T. Inuzuka : Appl. Phys. Lett. 71, 1065 (1997).

3) A. Kawano, H. Ishiwata, S. Iriyama, R. Okada, T. Yamaguchi, Y. Takano and H. Kawarada : Phys. Rev. B 82, 085318 (2010).

4) K. Ueda, M. Kasu, Y. Yamauchi, T. Makimoto, M. Schwitters, D.J. Twitchen, G.A. Scarsbrook and S.E. Coe : IEEE Electron Device Lett. 27, 570 (2006).

5) M. Kasu, K. Ueda, H. Ye, Y. Yamauchi, S. Sasaki and T. Makimoto : Electron. Lett. 41, 1249 (2005).

6) K. Hirama, H. Takayanagi, S. Yamauchi, Y. Jingu, H. Umezawa and H. Kawarada : IEEE International Electron Devices Meeting 2007 (IEDM 2007), Tech. Dig. 873 (2007).

7) I. Akasaki and H. Amano : Jpn. J. Appl. Phys. 36, 5393 (1997).

8) Y. Taniyasu, M. Kasu and N. Kobayashi : Appl. Phys. Lett. 81, 1255 (2002).

9) Y. Taniyasu, M. Kasu and T. Makimoto: Appl. Phys. Lett. 85, 4672 (2004).

10) Y. Taniyasu, M. Kasu and T. Makimoto: Appl. Phys. Lett. 89, 182112 (2006).

11) Y. Taniyasu, M. Kasu and T. Makimoto : Nature 441, 325 (2006).

12) Y.F. Wu, M. Moore, A. Saxler, T. Wisleder and P. Parikh : Proc. 64th DRC, Tech. Dig. 151 (2006).

13) J.W. Johnson, E.L. Piner, A. Vescan, R. Therrien, P. Rajagopal, J.C. Roberts, J.D. Brown, S. Singhal and K.J. Linthicum : IEEE Electron Device Lett. 25, 459 (2004).

14) A. Chini, J. Wittich, S. Heikman, S. Keller, S.P. DenBaars and U.K. Mishra: IEEE Electron Device Lett. 25, 55 (2004).

15) G. Vogg, C.R. Miskys, J.A. Garrido, M. Hermann, M. Eickhoff and M. Stutzmann: J. Appl. Phys. 96, 895 (2004).

16) M. Imura, K. Nakajima, M. Liao, Y. Koide and H. Amano : J. Cryst. Growth 312, 368 (2010).

17) K. Hirama, Y. Tanisyasu and M. Kasu : Jpn. J. Appl. Phys. 49, 04DH01 (2010).

18) Y. Taniyasu and M. Kasu : J. Cryst. Growth 311, 2825 (2009).

19) K. Hirama, Y. Taniyasu and M. Kasu : J. Appl. Phys. 108, 013528 (2010).

20) C.R. Miskys, J.A. Garrido, C.E. Nebel, M. Hermann, O. Ambacher, M. Eickhoff and M. Stutzmann : Appl. Phys. Lett. 82, 290 (2003). 